\title{
Extent of Knowledge of Coconut Farmers in Kozhikode District of Kerala
}

\author{
Greeshma Susan Mathew* and Allan Thomas*
}

\begin{abstract}
The present study was conducted among the coconut farmers of Kozhikode district of Kerala to assess the extent of knowledge on coconut cultivation. A total 120 farmers from purposively selected eight panchayats of the district formed the sample. Extent of knowledge of the farmers was measured using a teacher-made test. Based on analysis of data, it was found that more than half of the farmers possessed medium level of knowledge about the recommended coconut farming practices.
\end{abstract}

Keywords: Extent of knowledge; Coconut farmers; Kerala

Kerala's share in area and production of coconut in the country has declined over time. While Kerala accounted for 69.58 per cent of the area and 69.52 per cent of the production in the country in 1960-61, the corresponding shares declined to 40.2 per cent and 42.12 per cent respectively in 2011-12 (GoK, 2016).

The small size of holdings is the characteristic feature of land holdings in Kerala. Most of the holdings are less than 0.1 ha and only few farmers possess holdings of size above $0.40 \mathrm{ha}$. Since the size of holdings is small and most of these are homestead gardens, it could not generate adequate income to support the dependent families. Shortage of farm workers and high labour charges also force the farmers to ignore the timely adoption of agronomic practices and regular harvesting. Also, shift in cultivation to other remunerative crops like rubber, high cost of cultivation and low returns from coconut, prevalence of pests and diseases like root wilt, bud rot and alike could be the reasons for the negative growth rate in area and production yield. To overcome these constraints and boost up the production and productivity of the crop, the knowledge level of the farmers should be improved. Hence this study was taken up to assess the knowledge level of coconut growers.

\section{METHODOLOGY}

Extent of knowledge is operationally defined as the knowledge possessed by the coconut farmers on the recommended cultivation practices.In order to determine the extent of knowledge of the coconut farmers, a teacher made knowledge test was used. Major practices as per the package of practice recommendation of coconut

\footnotetext{
* Department of Agricultural Extension, College of Agriculture, Vellayani, Thiruvananthapuram, Kerala. India
} 
Table 1.

Teacher - made Test to Measure Extent of Knowledge

\begin{tabular}{|c|c|c|}
\hline SI. No. & Questions & Score \\
\hline 1 & What is the best time for planting the coconut seedlings? & \\
\hline 2 & $\begin{array}{l}\text { What is the spacing recommended by KAU (Kerala Agricultural } \\
\text { University) in planting coconut seedlings? }\end{array}$ & \\
\hline 3 & $\begin{array}{l}\text { Do you know that there should be 6-8 leaves in } 10-12 \text { month old } \\
\text { seedlings that are selected for planting? }\end{array}$ & \\
\hline 4 & What is the pit size for planting coconut seedlings & \\
\hline 5 & Whether the pits are filled by top soil while planting? & \\
\hline 6 & What is the height below the ground level to be filled with top soil? & \\
\hline 7 & $\begin{array}{l}\text { Do you know that the seedlings are to be removed from nursery by } \\
\text { lifting with spade and cutting the roots? }\end{array}$ & \\
\hline 8 & $\begin{array}{l}\text { What should be the frequency of irrigation for young palms upto } 2 \\
\text { years age, during dry summer months? }\end{array}$ & \\
\hline 9 & How many split doses of fertilizers are applied under rainfed conditions? & \\
\hline 10 & $\begin{array}{l}\text { How many split doses of fertilizers are applied under irrigated } \\
\text { conditions? }\end{array}$ & \\
\hline 11 & $\begin{array}{l}\text { Do you know the approximate quantity of fertilizers required for } \\
\text { the following fertilizers for a bearing palm under good management } \\
\text { conditions? }\end{array}$ & \\
\hline 12 & $\begin{array}{l}\text { Do you know about the beneficial effects of burial of husk in coconut } \\
\text { gardens? }\end{array}$ & \\
\hline 13 & $\begin{array}{l}\text { Do you know that the husk is to be buried in layers with concave } \\
\text { surface facing upwards? }\end{array}$ & \\
\hline 14 & $\begin{array}{l}\text { How many years the effect of husk burial will last in retaining moisture } \\
\text { in coconut gardens? }\end{array}$ & \\
\hline 15 & What should be applied on the trunk to minimize the sun scorch? & \\
\hline 16 & $\begin{array}{l}\text { Name the intercrops that are recommended in young coconut } \\
\text { plantation upto } 3-4 \text { years? }\end{array}$ & \\
\hline 17 & $\begin{array}{l}\text { Do you know about the method of leaf axil filling in coconut which } \\
\text { acts as a prophylactic measure? }\end{array}$ & \\
\hline
\end{tabular}


were included in the knowledge test to understand the existing knowledge of the respondent about coconut cultivation. Scores of 'one' and 'zero' were given to the correct and wrong answers respectively. The respondents were categorized into three groups based on the range of score attained and the mean value of the respondents.

A teacher made test was used to measure extent of knowledge (Table 1.)

Frequency and percentage analysis were carried out to find the distribution of farmers based on their extent of knowledge and they were classified into three categories namely low, medium and high based on the range of knowledge score.

\section{FINDINGS AND DISCUSSION}

Considering the extent of knowledge of coconut farmers in Kozhikode district of Kerala, it was found that more than half of the farmers had medium level of knowledge about the recommended practices in coconut.
The distribution of coconut farmers based on their extent of knowledge was recorded and are presented in Table 2 .

From the data presented in Table 2, it is clear that the mean value (14.85) was high indicating that majority of the respondents (about 85\%)had clear knowledge on the cultivation practices in coconut. More than half of the farmers (56.67\%) possessed medium level of knowledge about the recommended coconut farming practices. Similar result was reported by Jacob (2015). Only a small fraction of farmers (12.5\%) were yet to gain an equally better knowledge about the practices. This may be attributed to their low extension agency contact as ancertained by the author.

It can be concluded that farmers possessed medium level of knowledge in coconut farming in Kozhikode district of Kerala. This implies the need to strengthen the knowledge level of coconut farmers in Kerala for enhancing its production and productivity in farming.

Table 2

Distribution of Respondents based on Extent of Knowledge

\begin{tabular}{|c|l|c|c|}
\hline Sl. No. & \multicolumn{1}{|c|}{ Knowledge score } & Frequency & Percentage \\
\hline 1. & Low $(<13)$ & 15 & 12.50 \\
\hline 2. & Medium (13-15) & 68 & 56.67 \\
\hline 3. & High $(>15)$ & 37 & 30.83 \\
\hline & Total & 30 & 100 \\
\hline & $\begin{array}{l}\text { Mean=14.85; S.D =1.49; } \\
\text { SE=0.14 }\end{array}$ & & \\
\hline
\end{tabular}




\section{REFERENCES}

GoK. [Government of Kerala]. (2016). Farm Guide. Farm Information Bureau, Trivandrum, 333p.

Jacob, R. (2015). Technology assessment on the production practices of economically dominant crops in homegardens. Unpublished M.Sc.(Ag) thesis, Kerala Agricultural University, Thrissur, 139p. 